\title{
Critical values of nitrogen indices in tomato plants grown in soil and nutrient solution determined by different statistical procedures ${ }^{(1)}$
}

\author{
Paulo Cezar Rezende Fontes ${ }^{(2)}$ and Cláudio Pagotto Ronchi(3)
}

\begin{abstract}
The objective of this study was to establish critical values of the $\mathrm{N}$ indices, namely soilplant analysis development (SPAD), petiole sap $\mathrm{N}^{-\mathrm{NO}_{3}}$ and organic $\mathrm{N}$ in the tomato leaf adjacent to the first cluster (LAC), under soil and nutrient solution conditions, determined by different statistical approaches. Two experiments were conducted in randomized complete block design with four replications. Tomato plants were grown in soil, in $3 \mathrm{~L}$ pot, with five $\mathrm{N}$ rates $\left(0,100,200,400\right.$ and $\left.800 \mathrm{mg} \mathrm{kg}^{-1}\right)$ and in solution at $\mathrm{N}$ rates of $0,4,8,12$ and $16 \mathrm{mmol} \mathrm{L}^{-1}$. Experiments in nutrient solution and soil were finished at thirty seven and forty two days after transplanting, respectively. At those times, SPAD index and petiole sap $\mathrm{N}-\mathrm{NO}_{3}$ were evaluated in the LAC. Then, plants were harvested, separated in leaves and stem, dried at $70^{\circ} \mathrm{C}$, ground and weighted. The organic $\mathrm{N}$ was determined in LAC dry matter. Three statistical procedures were used to calculate critical $\mathrm{N}$ values. There were accentuated discrepancies for critical values of $\mathrm{N}$ indices obtained with plants grown in soil and nutrient solution as well as for different statistical procedures. Critical values of nitrogen indices at all situations are presented.
\end{abstract}

Index terms: Lycopersicon esculentum, nitrogen fertilizers, plant soil relations, statistical analysis.

Níveis críticos de índices de nitrogênio no tomateiro em solo e solução nutritiva determinados por diferentes procedimentos estatísticos

Resumo - O objetivo deste trabalho foi estabelecer os níveis críticos dos índices de N, SPAD ("soilplant analysis development"), $\mathrm{N}_{-} \mathrm{NO}_{3}$ na seiva do pecíolo e $\mathrm{N}$ orgânico na folha adjacente ao primeiro cacho do tomateiro (FAC), em solo e em solução nutritiva, determinados por diferentes procedimentos estatísticos. Foram conduzidos dois experimentos no delineamento em blocos casualizados, com quatro repetições. As plantas foram cultivadas em vasos contendo $3 \mathrm{~L}$ de solo, com cinco níveis de $\mathrm{N}(0,100$, 200, 400 e $800 \mathrm{mg} \mathrm{kg}^{-1}$ ) e, também, em solução nutritiva com $0,4,8,12$ e $16 \mathrm{mmol} \mathrm{L}^{-1}$ de nitrogênio. Os experimentos em solução e em solo foram encerrados aos 37 e 42 dias após o transplante, respectivamente. Nesta ocasião, o índice SPAD e o teor de $\mathrm{N}_{-} \mathrm{NO}_{3}$ foram determinados na FAC. Em seguida, as plantas foram colhidas, separadas em folhas e pecíolos, secadas a $70^{\circ} \mathrm{C}$, moídas e pesadas. Na matéria seca da FAC, foi determinado o $\mathrm{N}$ orgânico. Três procedimentos estatísticos foram utilizados para calcular o nível crítico. Verificaram-se acentuadas discrepâncias no valor do nível crítico dos índices de $\mathrm{N}$ obtidos com as plantas em solo e em solução nutritiva assim como utilizando-se diferentes procedimentos estatísticos. São apresentados os níveis críticos dos índices de $\mathrm{N}$ nas diversas situações.

Termos para indexação: Lycopersicon esculentum, adubo nitrogenado, relação planta-solo, análise estatística.

\section{Introduction}

Tomato (Lycopersicon esculentum Mill) is an important Brazilian vegetable crop having the nitro-

\footnotetext{
(1) Accepted for publication on January 7, 2002.

(2) Universidade Federal de Viçosa (UFV), CEP 36571-000

Viçosa, MG. CNPq fellow. E-mail: pacerefo@ufv.br

${ }^{(3)}$ UFV, Dep. de Fitotecnia. E-mail: ronchicp@yahoo.com.br
}

gen $(\mathrm{N})$ a major influence on the productivity levels. The goal of $\mathrm{N}$ management program should be supplying enough $\mathrm{N}$ to achieve maximum profit from the crop. But any $\mathrm{N}$ not used by the tomato crop is potentially subjected to leaching, which pollutes groundwater and decreases the efficiency of $\mathrm{N}$ fertilization. Efficient $\mathrm{N}$ management program in tomato production can be attained by suitable evaluation of plant nutritional status (Coltman, 1988; Smith \& Loneragan, 1997), usually accomplished by 
a quantitative analysis for the total $\mathrm{N}$ concentration, involving dry ashing procedure.

Alternatively to the total $\mathrm{N}$ determination, quick procedures have been proposed to evaluate tomato $\mathrm{N}$ status as the petiole-sap nitrate (Coltman, 1988; Hochmuth, 1994; Guimarães et al., 1998) and the leaf greenness determination by a hand-held device called Minolta SPAD (soil-plant analysis development) meter (Guimarães et al., 1999; Sandoval-Villa et al., 1999). SPAD index measured on plant leaves were positively correlated to $\mathrm{N}$ sufficiency for several crops (Piekielek \& Fox, 1992; Blackmer \& Scherpers, 1995; Shapiro, 1999; Rodrigues et al., 2000) and can be accepted as an $\mathrm{N}$ index.

Independently of the $\mathrm{N}$ index, the existence of values accepted as the critical $\mathrm{N}$ concentration is necessary to be used as a standard or reference. Usually, recommendation for critical values to evaluate $\mathrm{N}$ status are derived from tomato field survey and or field and greenhouse studies at soil and nutrient solution conditions in which tomato plant responses to a range of fertilizer rates are measured. Decision concerning optimal values involves fitting by a model that describes well the data. Model selection is a major factor affecting which rate is identified as being optimal (Cerrato \& Blackmer, 1990).

A limited survey of published reports indicates several models for best describing crop response to $\mathrm{N}$ fertilization, which depends on the $\mathrm{N}$ rates high enough to produce a clear maximum response, spaced $\mathrm{N}$ levels to adequately model the level-response relationship, appropriated plant growth, $\mathrm{N}$ absorption rates and fruit yield and utilization of variance analysis to estimate nutrient requirement from level response data. As a result, numerous standard $\mathrm{N}$ index values are published. Besides the chosen model as found for $\mathrm{N}$ rates (Cerrato \& Blackmer, 1990), type and age of tissue sampled (Mills \& Jones Junior, 1996; Smith \& Loneragan, 1997), and soil type (Guimarães et al., 1999), selected yield level and substrate characteristics may affect the values to be used as a reference or critical level.

The objectives of this study were to establish critical ranges of $\mathrm{N}$ indices, namely SPAD, petiole sap $\mathrm{N}-\mathrm{NO}_{3}$, and organic $\mathrm{N}$, in the tomato leaf adjacent to the first cluster under soil and nutrient solution conditions, estimated by different statistical approaches.

\section{Material and Methods}

Two experiments were carried out at greenhouse conditions in the Universidade Federal de Viçosa, MG, Brazil. The first was in soil, and the second in nutrient solution with tomato cultivar Santa Clara, in a randomized complete-block design with four replicates.

The first experiment was conducted on samples of the surface $20 \mathrm{~cm}$ of a silt clay soil. Soil samples were sieved thorough a $1 \times 1 \mathrm{~cm}$ opening screen, air dried, limed with $2 \mathrm{~g} \mathrm{dm}^{-3}$ and fertilized with $\mathrm{P}\left(435 \mathrm{mg} \mathrm{kg}^{-1}\right)$ and $\mathrm{K}$ (100 $\mathrm{mg} \mathrm{kg}^{-1}$ ). Five $\mathrm{N}$ levels were established, 0, 100, 200, 400 and $800 \mathrm{mg} \mathrm{kg}^{-1}$ by mixing $\left(\mathrm{NH}_{4}\right)_{2} \mathrm{SO}_{4}$ with the soil. Then, the soil was placed into $3 \mathrm{~kg}$ pots. One tomato seedling was transplanted into each pot.

The aerated nutrient solution experiment was conducted in $8 \mathrm{~L}$ pots containing $\mathrm{P}, \mathrm{K}, \mathrm{Ca}, \mathrm{Mg}$ and $\mathrm{S}$ at 2, 5.5, 4.5, 2 and $4 \mathrm{mmol} \mathrm{L}^{-1}$, respectively, and micronutrient concentrations following Hoagland \& Arnon (1950). Five N rates, $0,4,8,12$, and $16 \mathrm{mmol} \mathrm{L}^{-1}$ were evaluated, being $20 \%$ as $\mathrm{N}-\mathrm{NH}_{4}$ and $80 \%$ as $\mathrm{N}^{-N^{-1}}{ }_{3}$. The solution was adjusted daily to $\mathrm{pH} 5.8 \pm 0.3$ with $\mathrm{NaOH}$ or $\mathrm{HCl}$ and the pots volumes were completed with deionized water. One tomato seedling was transferred to each pot.

After the beginning of the tomato plant reproductive phase, 37 and 42 days after seedling transplanting to solution and soil experiments, respectively, petiole-sap nitrate (PSN) and SPAD (soil-plant analysis development) indices were measured in the leaf adjacent to the cluster (LAC). A Minolta SPAD 502 meter was used to take chlorophyll readings, taken on the terminal leaflet of the LAC. Then, the LAC petiole base was cut at $2 \mathrm{~cm}$ from its insertion in the stem and crushed in a stainless steel garlic crusher. Sap was collected on the meter's electrode (C-141 Cardy Nitrate Meter - HORIBA, Inc.) and the $\mathrm{N}-\mathrm{NO}_{3}$ concentration was read at the digital meter. Then, the LAC was harvested, dried, ground to pass a $1 \mathrm{~mm}$ sieve, ashed with sulphuric acid and analyzed colorimetrically for organic $\mathrm{N}$ (Jackson, 1958). After SPAD and PSN determinations, the plant top was cut off at the cotyledonary node, and dried in a forced air oven at $70^{\circ} \mathrm{C}$, and the shoot dry weight (SDW) was recorded.

In each experiment, $\mathrm{N}$ effect levels on PSN, SPAD index, $\mathrm{N}$ concentration in LAC dry matter (ORN) and SDW were analyzed by analysis of variance. Next, three statistical procedures were used to calculate the critical $\mathrm{N}$ indices. By the procedure named one, linear, quadratic, square root, potential, exponential, hyperbolic, logarithmic and cubic root models were fitted to statistically significant data using $\mathrm{N}$ level as the independent variable. The best fitting model with biological logic was used to estimate the 
maximum SDW obtained by equating the first derivatives of the best fitting model to zero, solving for X, substituting the $\mathrm{X}$ values into the model and solving for $\mathrm{Y}$. To estimate PSN, SPAD index and ORN critical values in both experiments, $\mathrm{N}$ rate associated to maximum $\mathrm{SDW}\left(\mathrm{CV}_{100}\right)$ was introduced into the best fit model previously determined, which correlates PSN, SPAD index and ORN to N level. The model also was used to determine the PSN, SPAD index and ORN critical values associated to 99.9, 99,95 , and $90 \%$ of the maximum SDW.

By the procedure named two, the steps were the same as in number one, but the best fitting model, with biological logic, was chosen among only linear, quadratic and cubic models.

By the procedure named three, all models listed in the procedure number one were fitted to PSN, SPAD index and ORN as independent variables (X) and the SDW as the dependent variable (Y). In each experiment, the best fitting model with biological logic within the range of observed $\mathrm{X}$ values was used to estimate PSN, SPAD index and $\mathrm{NDM}$ critical values at $\mathrm{CV}_{100}, \mathrm{CV}_{99.9}, \mathrm{CV}_{99}, \mathrm{CV}_{95}$, and $\mathrm{CV}_{90}$.

\section{Results and Discussion}

By the procedure named one, tomato shoot dry weight $(\mathrm{SDW})$ responded $(\mathrm{p}<0.01)$ to applied $\mathrm{N}$ levels until they reached maximum values of 21.67 and $27.75 \mathrm{~g}_{\text {plant }}{ }^{-1}$ at $172 \mathrm{mg} \mathrm{kg}^{-1}$ and $6.35 \mathrm{mmol} \mathrm{L}^{-1}$ in soil and nutrient solution, respectively (Figure 1). By the procedure named two, the corresponded values were 21.71 and $26.97 \mathrm{~g}$ plant $^{-1}$ at $351 \mathrm{mg} \mathrm{kg}^{-1}$ and $9.43 \mathrm{mmol} \mathrm{L}^{-1}$, respectively (Figure 1). As expected, less than maximum shoot dry weight was obtained with lower $\mathrm{N}$ rates (Table 1). Several authors found negative effects of high $\mathrm{N}$ levels in soil (Guimarães et al., 1999) and in nutrient solution (Fontes et al., 1995) on tomato SDW. N nutrition enhances metabolic processes that influence the physicochemical environment at the soil-root interface, interfere with the uptake of cations and anions, enhance or repress several enzyme system activities, and affect plant growth patterns (Fernandes \& Rossielo, 1995). High $\mathrm{N}-\mathrm{NO}_{3}$ levels decrease important aminoacids formation and change the vacuolar $\mathrm{pH}$ due to $\mathrm{N}-\mathrm{NO}_{3}$ accumulation (Mohamed et al., 1987) and high $\mathrm{N}_{-} \mathrm{NH}_{4}$ levels disrupt biological membranes, uncouple photophosphorylation, block ATP production, reduce $\mathrm{CO}_{2}$ fixation and decrease nutrient absorption, mainly $\mathrm{Ca}, \mathrm{Mg}$, and K (Claassen \& Wilcox, 1974).

The two models predicted similar maximum SDWs but $\mathrm{N}$ levels to achieve them in soil and nutrient solution were in average $104 \%$ and $48 \%$ higher when procedure two was utilized instead of procedure one (Table 1). Tomato plants grown in solution were more efficient to utilize $\mathrm{N}$ than plants in soil. In solution,
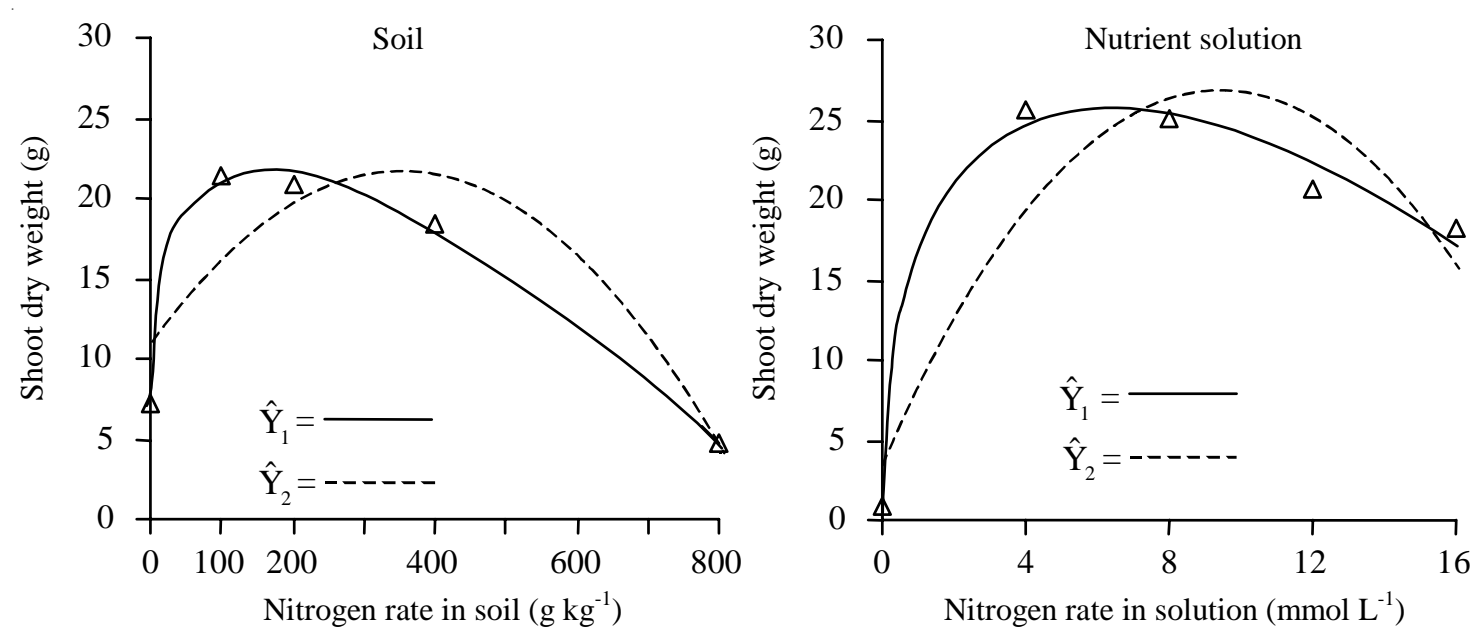

Figure 1. Relationships between tomato plant shoot dry weight and nitrogen application rate in soil established by procedures named one $\left(\hat{Y}_{1}=7.263+2.259 \mathrm{X}^{0.5}-0.0933 \mathrm{X}+0.000366 \mathrm{X}^{1.5}, \mathrm{R}^{2}=0.996\right)$ and two $\left(\hat{\mathrm{Y}}_{2}=10.998+0.0610 \mathrm{X}-\right.$ $\left.0.0000871 \mathrm{X}^{2}, \mathrm{R}^{2}=0.794\right)$ and in nutrient solution established by procedures one $\left(\hat{\mathrm{Y}}_{1}=0.993+19.635 \mathrm{X}^{0.5}-3.893 \mathrm{X}\right.$, $\left.\mathrm{R}^{2}=0.989\right)$ and two $\left(\hat{\mathrm{Y}}_{2}=3.762+4.9216 \mathrm{X}-0.2605 \mathrm{X}^{2}, \mathrm{R}^{2}=0.811\right)$. 
estimated by model one, the maximum tomato SDWs per g of added $\mathrm{N}$ was $312 \mathrm{mg}$ and only $126 \mathrm{mg}$ in soil, that is $148 \%$ higher. The corresponded value estimated by model two was $229 \%$ higher. Depending on the growth conditions, $\mathrm{N}$ efficiency of young tomato plant would range from 27 (Sampaio et al., 1995) to $332 \mathrm{mg} \mathrm{g}^{-1}$ (Guimarães et al., 1999).

Estimated by procedures one and two, petiolesap nitrate levels in tomato plants grown in soil
(Figure 2) and SPAD indices (Figure 3) and organicnitrogen (Figure 4) values in plant grown in both soil and nutrient solution were increased $(\mathrm{p}<0.01)$ by increasing $\mathrm{N}$ rate up to determined value within the experimental space; petiole-sap nitrate levels in plants under nutrient solution conditions were increased $(\mathrm{p}<0.01)$ by $\mathrm{N}$ rates. Sap test measures $\mathrm{N}-\mathrm{NO}_{3}$ present in xylem and phloem sap plus the apoplastic, citosolic and vacuolar water. It is a direct

Table 1. Tomato shoot dry weight (SDW) and nitrogen levels (NL) in soil and in nutrient solution predicted by procedures named one and two, at several percentage of the maximum.

\begin{tabular}{|c|c|c|c|c|c|c|}
\hline \multirow[t]{2}{*}{ Variable } & \multirow{2}{*}{$\begin{array}{l}\text { Procedure } \\
\text { number }^{(1)}\end{array}$} & \multicolumn{5}{|c|}{ Percent of the maximum } \\
\hline & & 100 & 99.9 & 99 & 95 & 90 \\
\hline \multirow{6}{*}{ SDW } & & & & Soil (g pla & & \\
\hline & One & 21.67 & 21.65 & 21.45 & 20.58 & 19.50 \\
\hline & Two & 21.71 & 21.69 & 21.50 & 20.63 & 19.54 \\
\hline & & \multicolumn{5}{|c|}{ Nutrient solution $\left(\mathrm{g}_{\text {plant }}{ }^{-1}\right)$} \\
\hline & One & 25.75 & 25.73 & 25.50 & 24.47 & 23.18 \\
\hline & Two & 26.97 & 26.94 & 26.70 & 25.62 & 24.27 \\
\hline \multirow{6}{*}{ NL } & & & & Soil (mg k & & \\
\hline & One & 172 & 158 & 132 & 89 & 63 \\
\hline & Two & 351 & 334 & 301 & 203 & 193 \\
\hline & & \multicolumn{5}{|c|}{ Nutrient solution $\left(\mathrm{mmol} \mathrm{L}^{-1}\right)$} \\
\hline & One & 6.36 & 5.96 & 5.13 & 3.79 & 2.92 \\
\hline & Two & 9.43 & 9.11 & 8.41 & 7.15 & 6.21 \\
\hline
\end{tabular}

(1)In the procedure number one the best fitting model selected among linear, quadratic, square root, potential, exponential, hyperbolic, logarithmic and cubic root models was used; in the procedure number two only linear, quadratic and cubic models were used.
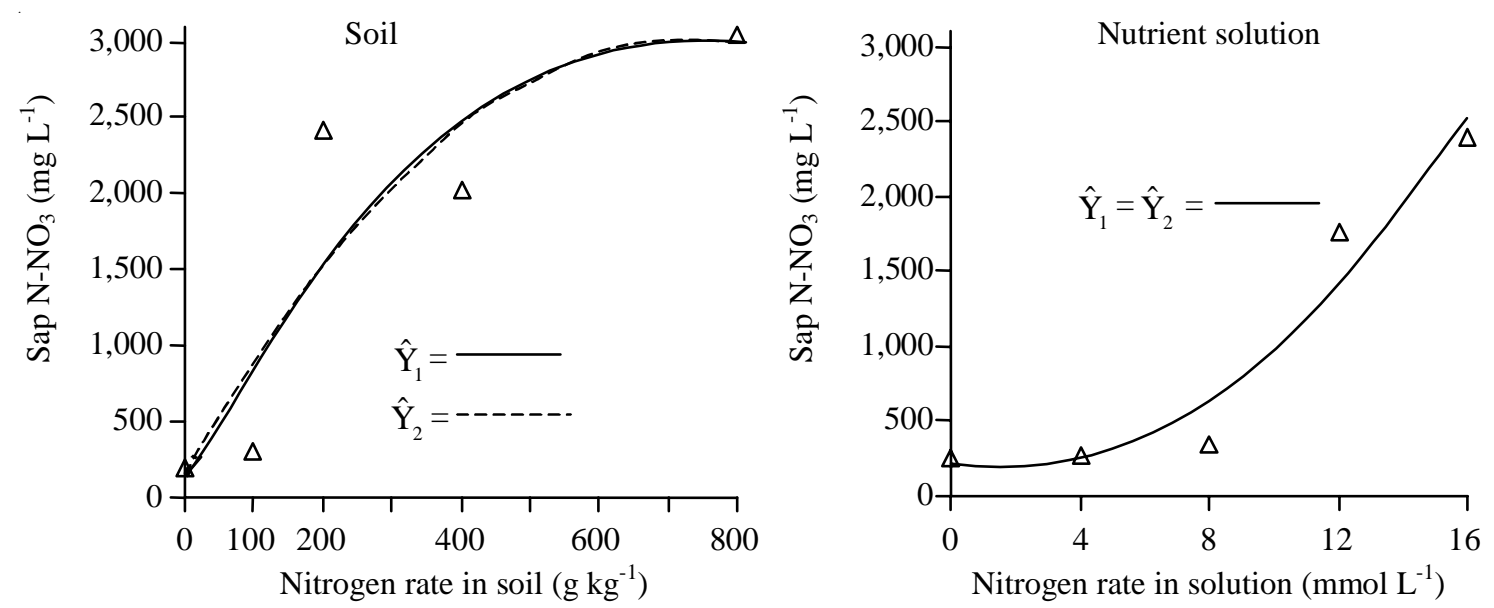

Figure 2. Relationships between sap $\mathrm{N}-\mathrm{NO}_{3}$ in tomato leaf adjacent to the first cluster and nitrogen application rate in soil established by procedures named one $\left(\hat{\mathrm{Y}}_{1}=146.425-40.498 \mathrm{X}^{0.5}+14.711 \mathrm{X}-0.344 \mathrm{X}^{1.5}, \mathrm{R}^{2}=0.803\right)$ and two $\left(\hat{\mathrm{Y}}_{2}=153.615+7.920 \mathrm{X}-0.00547 \mathrm{X}^{2}, \mathrm{R}^{2}=0.796\right)$ and in nutrient solution by procedures one $\left(\hat{\mathrm{Y}}_{1}\right)$ and $=$ two $\left.\left(\hat{\mathrm{Y}}_{2}\right)=221.357-40.991 \mathrm{X}+11.574 \mathrm{X}^{2}, \mathrm{R}^{2}=0.943\right)$. 
measure of current $\mathrm{N}$ supply and is markedly affected by many factors among them the light intensity (Fukuda et al., 1999).

The SPAD index of plant leaves supplied with high amount of $\mathrm{N}$ were significantly greater than when low amount or no $\mathrm{N}$ was applied (Figure 3). It was also greater in plants grown in soil than in solution. The SPAD index detects the transmittance of light emitted by two diodes, one with a peak absorbance at $650 \mathrm{~nm}$ and the other one at $940 \mathrm{~nm}$. In the first one, there was high light absorptance by chlorophyll and in the second one light absorptance was
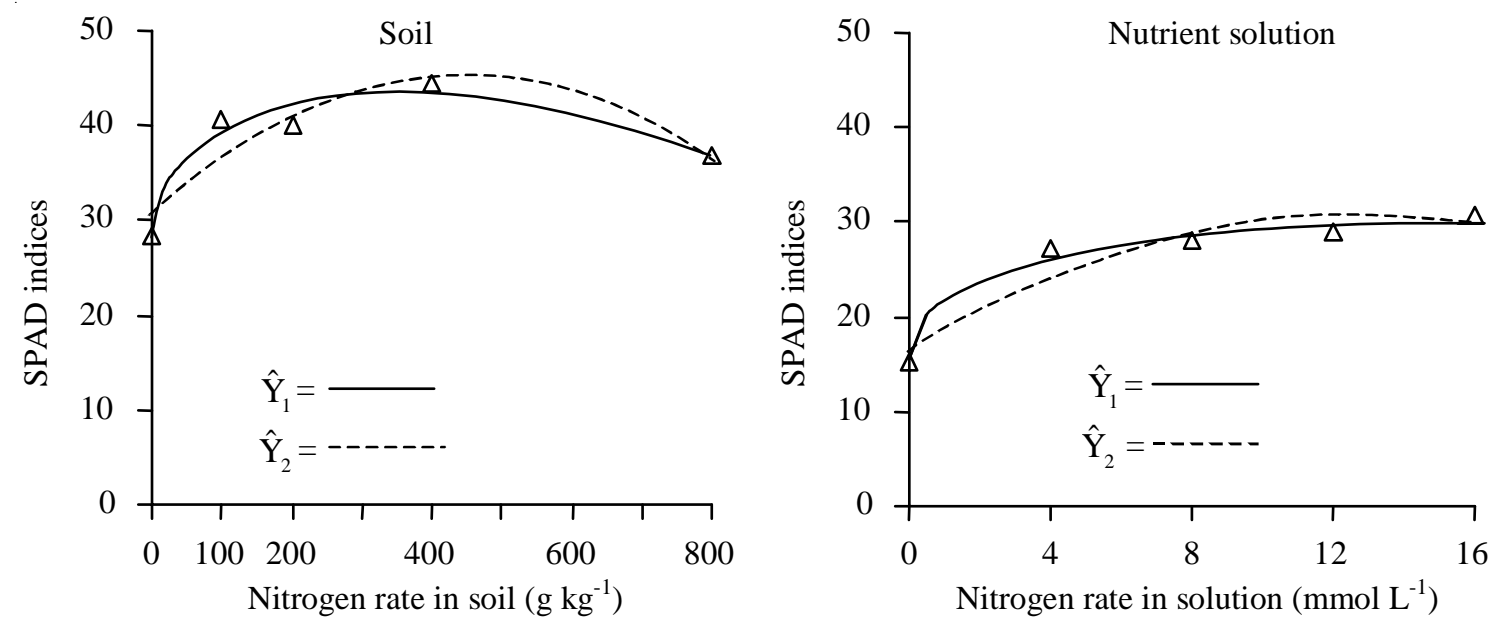

Figure 3. Relationships between SPAD (soil-plant analysis development) indices in tomato leaf adjacent to the first cluster and nitrogen application rate in soil established by procedures named one $\left(\hat{\mathrm{Y}}_{1}=28.409+1.246 \mathrm{X}^{0.5}-0.00549 \mathrm{X}-\right.$ $\left.0.000985 \mathrm{X}^{1.5}, \mathrm{R}^{2}=0.945\right)$ and two $\left(\hat{\mathrm{Y}}_{2}=30.639+0.0665 \mathrm{X}-0.0000739 \mathrm{X}^{2}, \mathrm{R}^{2}=0.827\right)$ and in nutrient solution by procedures one $\left(\hat{\mathrm{Y}}_{1}=15.371+7.308 \mathrm{X}^{0.5}-0.917 \mathrm{X}, \mathrm{R}^{2}=0.986\right)$ and two $\left(\hat{\mathrm{Y}}_{2}=16.551+2.289 \mathrm{X}-0.0923 \mathrm{X}^{2}, \mathrm{R}^{2}=0.898\right)$.
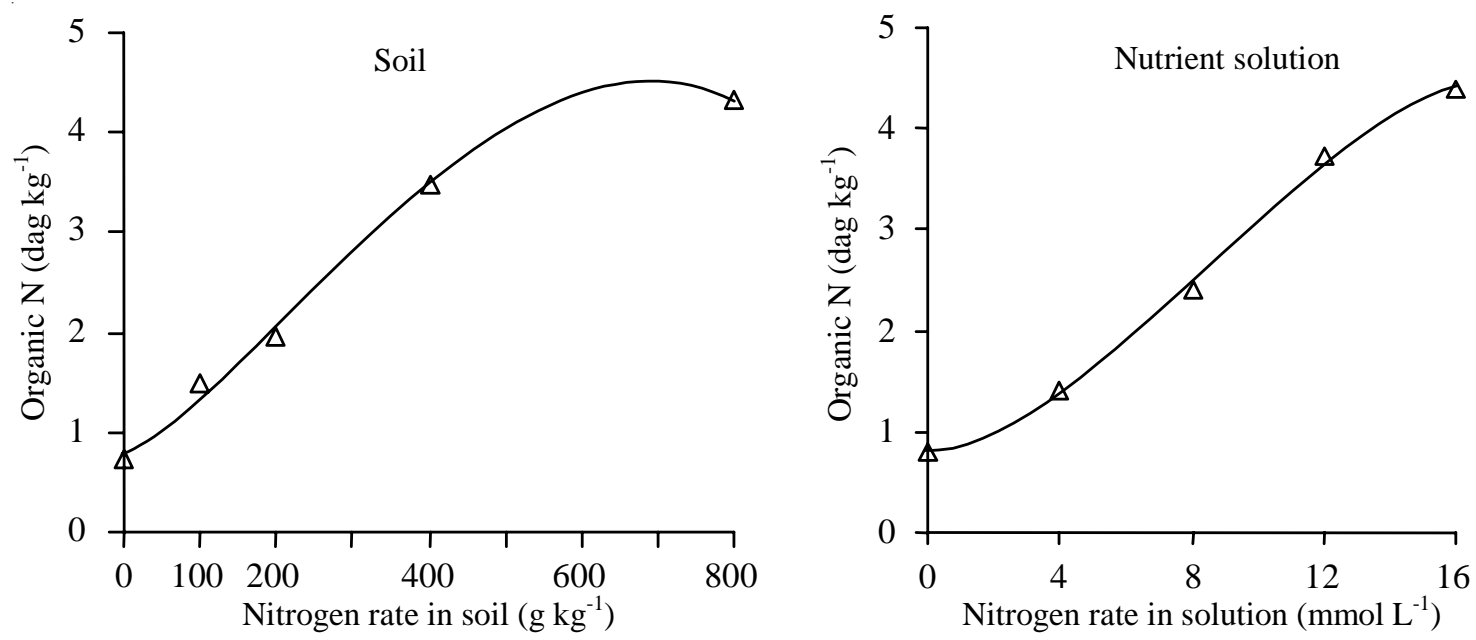

Figure 4. Relationships between organic nitrogen in tomato leaf adjacent to the first cluster and nitrogen application rate in soil established by procedures named one $\left(\hat{\mathrm{Y}}_{1}\right)$ and $=$ two $\left(\hat{\mathrm{Y}}_{2}\right)=0.781+0.00496 \mathrm{X}+0.00000945 \mathrm{X}^{2}-$ $\left.0.00000000127 \mathrm{X}^{3}, \mathrm{R}^{2}=0.997\right)$ and in nutrient solution by procedures one $\left(\hat{\mathrm{Y}}_{1}\right)$ and $=$ two $\left(\hat{\mathrm{Y}}_{2}\right)=0.807+0.0244 \mathrm{X}+$ $\left.0.0335 \mathrm{X}^{2}-0.00131 \mathrm{X}^{3}, \mathrm{R}^{2}=0.998\right)$. 
negligible. So, the SPAD index represents the light transmittance ratio through the leaf tissue at those wavelengths and may be used to provide a rapid estimate of leaf transmittance and reflectance in the field (Madeira et al., 2000).

Peculiar to plant species (Marquard \& Tipton, 1987) and growth conditions (Campbell et al., 1990; Guimarães, 1998), positive relationship has been demonstrated between SPAD readings and chlorophyll contents in leaves. With increase in chlorophyll content, light absorption by plant leaves increases. Chlorophyll is responsible for leaf greenness and generally recognized as an indication of $\mathrm{N}$ status for many crops. Intensity of green colour leaves has been used as an index of $\mathrm{N}$ concentration in the leaves (Takebe et al., 1990) as long as the concentration of $\mathrm{N}$ in nitrate form be low. Ali et al. (1999) found that N-deficient yellowish leaves contained small amounts of RuBisCO but when excess of $\mathrm{N}$ fertilizer is applied, the leaves function was significantly less efficient in spite of high chlorophyll and RuBisCO contents.

Tomato leaf green color was less intense in solution culture than in soil as indicated by the SPAD values (Figure 2). Due to position in the greenhouse, plants grown in nutrient solution were more shaded than in soil influencing the light irradiance on tomato which may affect chloroplast orientation in leaves (Hoel \& Solhaug, 1998). Furthermore, in solution $\mathrm{P}, \mathrm{Mg}, \mathrm{Mn}, \mathrm{Zn}, \mathrm{Cu}, \mathrm{Fe}, \mathrm{S}$, and $\mathrm{K}$ concentrations in leaves were lower than in leaves of tomato plants grown in soil. The inverse was true for $\mathrm{Ca}$ and $\mathrm{B}$. Partial $\mathrm{Ca}$ and $\mathrm{Mg}$ deficiencies but $\mathrm{K}$ decreased chlorophyll contents in lemon leaves (Lavon et al., 1999).

Relationships between $\mathrm{N}$ indices and tomato shoot dry weight (SDW), under soil and nutrient solution, which were utilized for critical level determination by procedure named three, are presented (Table 2). In all situations, but SPAD indices in plants grown in soil, SDW values increased with increasing $\mathrm{N}$ indices up to a maximum point which was the critical value $\left(\mathrm{CV}_{100}\right)$ estimated by procedure named three (Table 3). $\mathrm{CV}_{100}$ for SPAD index in soil was 44.4 , estimated with the maximum observed SDW value (22.15 g plant $\left.^{-1}\right)$.

As expected, all critical $\mathrm{N}$ indices in tomato plants grown in soil and nutrient solution were higher when $100 \%$ maximum shoot dry weight was selected (Table 3). Higher maximum values selection implied in relatively low decrease in shoot dry weight and high decrease in $\mathrm{N}$ rates (Table 1). There were considerable disagreement among the statistical procedures, substrates and yield levels selected to estimate critical $\mathrm{N}$ indices in tomato leaf, indicating a need to emphasize them when setting critical values (Table 3).

As the price of $\mathrm{N}$ fertilizer decreases relatively to the price of tomato fruit, high percentage of the maximum yield should be chose but fertilization levels of $\mathrm{N}$ to give $100 \%$ of fruit yield usually are not economic and/or ecological optimal. In this paper, it is assumed that $\mathrm{N}$ index estimated by procedures one and three for $99 \%$ of the maximum shoot dry weight are the critical range values $\left(\mathrm{CV}_{99}\right)$.

Table 2. Nitrogen indices $(\mathrm{X})$ in tomato leaf adjacent to the first cluster related to shoot dry weight $\left(\mathrm{g}\right.$ plant $\left.{ }^{-1}\right)$ in soil and nutrient solution.

\begin{tabular}{|c|c|c|}
\hline $\mathrm{N}$ indices $(\mathrm{X})$ & Regression equations & $\mathrm{R}^{2}$ \\
\hline \multicolumn{3}{|c|}{ Soil } \\
\hline Sap N-NO ${ }_{3}\left(\mathrm{mg} \mathrm{L}^{-1}\right)$ & $\hat{Y}=9.564+0.0266 X-0.0000120 X^{2}$ & 0.558 \\
\hline $\mathrm{SPAD}^{(1)}$ index & $\hat{Y}=206.530-77.0726 X^{0.5}+7.414 X$ & 0.545 \\
\hline $\mathrm{N}$ in leaf $\mathrm{DM}^{(2)}\left(\mathrm{dag} \mathrm{kg}^{-1}\right)$ & $\hat{\mathrm{Y}}=-17.025+1.5409 \mathrm{X}^{0.5}+50.287 \mathrm{X}-22.0837 \mathrm{X}^{1.5}$ & 0.959 \\
\hline \multicolumn{3}{|c|}{ Nutrient solution } \\
\hline Sap N-NO ${ }_{3}\left(\mathrm{mg} \mathrm{L}^{-1}\right)$ & $\hat{Y}=-20.727+2.664 X^{0.5}-0.0359 X$ & 0.427 \\
\hline SPAD index & $\hat{Y}=-611.473+260.1946 X^{0.5}-26.469 X$ & 0.989 \\
\hline $\mathrm{N}$ in leaf $\mathrm{DM}\left(\mathrm{dag} \mathrm{kg}^{-1}\right)$ & $\hat{\mathrm{Y}}=-102.045+163.2808 \mathrm{X}^{0.5}-50.827 \mathrm{X}$ & 0.876 \\
\hline
\end{tabular}

(1)SPAD: soil-plant analysis development. (2)DM: dry matter. 
In soil, $\mathrm{PSN}$ critical concentrations for $\mathrm{CV}_{99}$ estimated by procedures one and three ranged from 966 to $1,098 \mathrm{mg} \mathrm{L}^{-1}$ (Table 3). Corresponding values in nutrient solutions were 315 to $1,175 \mathrm{mg} \mathrm{L}^{-1}$ (Table 3 ). Published values of optimum PSN are 1,000 to 1,200 (Hochmuth, 1994); 1,091 (Coltman, 1987); 960 to 1,160 in spring tomato crop or 776 to 996 for the fall crop (Rhoads et al., 1996); and 2,581 $\mathrm{mg} \mathrm{L}^{-1}$ in situation with six N applications (Guimarães et al., 1998).

Critical SPAD indices for $\mathrm{CV}_{99}$ estimated by procedures one and three ranged from 40.3 to 44.2 in plants under soil conditions and the corresponding values in plants grown in nutrient solution were 27.2 to 23.2 (Table 3). SPAD index measures leaf greenness ranging from 0 to 80 with a higher number representing a greener leaf (Dwyer et al., 1995). At two different soil type, SPAD critical values in tomato leaf adjacent to the cluster measured at flowering stage were 35.5 and 46.5 (Guimarães et al., 1999). SPAD values of 43.4 and 52.0 in corn were established to distinguish between responsive and non-responsive site to sidedress N (Piekielek \& Fox, 1992; Smeal \& Zhang, 1994; Piekielek et al., 1995).

In plants grown in soil, leaf organic $\mathrm{N}$ critical concentrations for $\mathrm{CV}_{99}$ estimated by procedures one and three ranged from 1.57 to $2.07 \mathrm{dag} \mathrm{kg}^{-1}$ and the corresponding values in plants grown in nutrient solution were 1.63 to $2.34 \mathrm{dag} \mathrm{kg}^{-1}$ (Table 3). These values are lower than 2.80 to $4.20 \mathrm{dag} \mathrm{kg}^{-1}$ indicated by Mills \& Jones Junior (1996) for tomato plants under greenhouse conditions. There are also lower than 3.02 and $3.43 \mathrm{dag} \mathrm{kg}^{-1}$ found by Sampaio et al.

Table 3. Critical values of nitrogen indices in tomato leaf adjacent to the first cluster (LAC) associated with different percentages of the maximum shoot dry weight in soil and nutrient solution determined by three different statistical procedures.

\begin{tabular}{|c|c|c|c|c|c|c|}
\hline \multirow[t]{2}{*}{$\mathrm{N}$ index } & \multirow{2}{*}{$\begin{array}{l}\text { Procedure } \\
\text { number }^{(1)}\end{array}$} & \multicolumn{5}{|c|}{ Percent of the maximum } \\
\hline & & 100 & 99.9 & 99 & 95 & 90 \\
\hline \multirow{8}{*}{ Sap N-NO ${ }_{3}\left(\mathrm{mg} \mathrm{L}^{-1}\right)$} & & & & Soil & & \\
\hline & One & 1,370 & 1,283 & 1,098 & 786 & 580 \\
\hline & Two & 2,260 & 2,193 & 2,042 & 1,735 & 1,478 \\
\hline & Three & 1,108 & 1,064 & 966 & 789 & 658 \\
\hline & & \multicolumn{5}{|c|}{ Nutrient solution } \\
\hline & One & 428 & 390 & 315 & 232 & 200 \\
\hline & Two & 864 & 808 & 695 & 521 & 413 \\
\hline & Three & 1,377 & 1,313 & 1,175 & 947 & 792 \\
\hline \multirow{8}{*}{$\mathrm{SPAD}^{(2)}$ index } & & & & Soil & & \\
\hline & One & 41.6 & 41.3 & 40.3 & 38.9 & 37.5 \\
\hline & Two & 44.9 & 44.6 & 44.0 & 42.3 & 40.7 \\
\hline & Three & 44.4 & 44.3 & 44.2 & 43.7 & 42.9 \\
\hline & & \multicolumn{5}{|c|}{ Nutrient solution } \\
\hline & One & 28.0 & 27.8 & 27.2 & 26.1 & 25.2 \\
\hline & Two & 29.9 & 29.7 & 29.3 & 28.2 & 27.2 \\
\hline & Three & 24.2 & 23.8 & 23.2 & 21.9 & 21.2 \\
\hline \multirow{8}{*}{$\begin{array}{l}\mathrm{N} \text { in leaf dry matter } \\
\left(\text { dag kg }^{-1}\right)\end{array}$} & & & & Soil & & \\
\hline & One & 1.85 & 1.75 & 1.57 & 1.29 & 1.13 \\
\hline & Two & 3.14 & 3.03 & 2.78 & 2.33 & 2.00 \\
\hline & Three & 2.27 & 2.21 & 2.07 & 1.83 & 1.65 \\
\hline & & \multicolumn{5}{|c|}{ Nutrient solution } \\
\hline & One & 1.98 & 1.87 & 1.63 & 1.31 & 1.13 \\
\hline & Two & 2.92 & 2.82 & 2.60 & 2.22 & 1.94 \\
\hline & Three & 2.58 & 2.50 & 2.34 & 2.06 & 1.87 \\
\hline
\end{tabular}

(1) In the procedure number one the best fitting model selected among linear, quadratic, square root, potential, exponential, hyperbolic, logarithmic and cubic root models was used; in the procedure number two, only linear, quadratic and cubic models were used; in the procedure number three the same models were used as in the procedure number one, being all this nitrogen indices as independent variable (X), and the shoot dry weight as the dependent variable (Y). ${ }^{(2)}$ SPAD: soil-plant analysis development. 
(1995) and Guimarães et al. (1998) for tomato plants grown in nutrient solution and soil under greenhouse conditions, respectively. Several reasons led to different critical levels being the timing of $\mathrm{N}$ application, that is $\mathrm{N}$ availability, and the sink demand or dry matter yield the most significatives. In both experiments, tomato plants were harvested before fruit setting and it would be interesting to test if so small $\mathrm{N}$ concentrations in leaf tissue maintained through the entire plant cycle by daily or weekly $\mathrm{N}$ additions would led to profitable fruit yield.

\section{Conclusion}

Critical values of nitrogen indices in tomato plant leaf depend on substrate and statistical procedure utilized.

\section{References}

ALI, K.; NII, N.; YAMAGUCHI, K.; NISHIMURA, M. Levels of nonstructural carbohydrate in leaves and roots and some characteristics of chloroplasts after application of different amounts of nitrogen fertilizer to peach seedlings. Journal of the Japanese Society for Horticultural Science, v. 68, p. 717-723, 1999.

BLACKMER, T. M.; SCHERPERS, J. S. Use of a chlorophyll meter to monitor nitrogen status and schedule fertigation for corn. Journal of Production Agriculture, Madison, v. 8, p. 56-60, 1995.

CAMPBELL, R. J.; MOBLEY, K. N.; MARINI, R. P.; PFEIFFER, D. G. Growing conditions alter the relationships between SPAD-501 values and apple leaf chlorophyll. HortScience, Alexandria, v. 25, p. 330-331, 1990.

CERRATO, M. E.; BLACKMER, A. M. Comparison of models for describing corn yield response to nitrogen fertilizer. Agronomy Journal, Madison, v. 82, p. 138-143, 1990.

CLAASSEN, M. E. T.; WILCOX, G. E. Effect of nitrogen forms on growth and composition of tomato and peas tissue. Journal of the American Society for Horticulture Science, Alexandria, v. 99, p. 171-174, 1974.

COLTMAN, R. R. Sampling considerations for nitrate quick tests of greenhouse grown tomatoes. Journal of the American Society for Horticulture Science, Alexandria, v. 112, p. 922-927, 1987.
COLTMAN, R. R. Yields of greenhouse tomatoes managed to maintain specific petiole sap nitrate level. HortScience, Alexandria, v. 23, n. 1, p. 148-151, 1988.

DWYER, L. M.; ANDERSON, A. M.; MA, B. L.; STEWART, D. W.; TOLLENAAR, M.; GREGORICH, E. Quantifying the nonlinearity in chlorophyll meter response to corn leaf nitrogen concentration. Canadian Journal of Plant Science, Ottawa, v. 75, p. 179-182, 1995.

FERNANDES, M. S.; ROSSIELO, R. O. P. Mineral nitrogen in plant physiology and plant nutrition. Critical Reviews in Plant Sciences, Boca Raton, v. 14, n. 2, p. 111-148, 1995.

FONTES, P. C. R.; GOMES, J. M.; PEREIRA, P. R. G.; MARTINEZ, H. E. P. Nível crítico de $\mathrm{N}-\mathrm{NO}_{3}$ em pecíolos de tomateiro extraído por diferentes métodos. Horticultura Brasileira, Brasília, v. 13, n. 1, p. 11-13, 1995.

FUKUDA, N.; MIYAGI, M.; SUZUKI, Y.; IKEDA, H.; TAKAYANAGI, K. Effects of supplemental night lighting and $\mathrm{NO}_{3}$-exclusion on the growth and $\mathrm{NO}_{3}$-concentration in the leaf sap of greenhouse-grown spinach under NFT. Journal of the Japanese Society for Horticultural Science, Tokyo, v. 68, n. 1, p. 146-151, 1999.

GUIMARÃES, T. G. Nitrogênio no solo e na planta, teor de clorofila e produção do tomateiro, no campo e na estufa, influenciados por doses de nitrogênio. 1998. $184 \mathrm{f}$. Tese (Doutorado) - Universidade Federal de Viçosa, Viçosa.

GUIMARÃES, T. G.; FONTES, P. C. R.; PEREIRA, P. R. G.; ALVAREZ VENEGAS, H. V.; MONNERAT, P. H. Determinação dos teores de nitrogênio na seiva do tomateiro por meio de medidor portátil. Horticultura Brasileira, Brasília, v. 16, n. 2, p. 144-151, 1998.

GUIMARÃES, T. G.; FONTES, P. C. R.; PEREIRA, P. R. G.; ALVAREZ VENEGAS, H. V.; MONNERAT, P. H. Teores de clorofila determinados pela metodologia convencional e por medidor portátil, suas correlações e a relação com formas de nitrogênio em folhas de tomateiros, cultivados em dois tipos de solos. Bragantia, Campinas, v. 58 , n. 1 , p. 209-216, 1999.

HOAGLAND, D. A.; ARNON, D. I. The water culture method for growing plants without soil. Berkeley: California Agriculture Experimental Station, 1950. 39 p. (Circular, 347). 
HOCHMUTH, G. J. Sufficiency ranges for nitrate-nitrogen and potassium for vegetable petiole sap quick tests. HortTechnology, Alexandria, v. 4, p. 218-222, 1994.

HOEL, B. O.; SOLHAUG, K. A. Effect of irradiance on chlorophyll estimation with the Minolta SPAD-502 leaf chlorophyll meter. Annals of Botany, London, v. 82, p. 389-392, 1998.

JACKSON, M. L. Soil chemical analysis. Englewood Cliffs: Prentice Hall, 1958. 498 p.

LAVON, R.; SALOMON, R.; GOLDSCHMIDT, E. E. Effects of $\mathrm{K}, \mathrm{Mg}$, and $\mathrm{Ca}$ deficiencies on nitrogen constituents and chloroplast components in citrus leaves. Journal of the American Society for Horticultural Science, Alexandria, v. 124, n. 2, p. 158-162, 1999.

MADEIRA, A. C.; MENDONÇA, A.; FERREIRA, M.; TABORDA, M. L. Relationship between spectroradiometric and chlorophyll measurements in green beans. Communications in Soil Science and Plant Analysis, New York, v. 31, p. 631-643, 2000.

MARQUARD, R. D.; TIPTON, J. L. Relationship between extractable chlorophyll and an in situ method to estimate leaf greenness. HortScience, Alexandria, v. 22, n. 6, p. $1327,1987$.

MILLS, H. A.; JONES JUNIOR, J. B. Plant analysis handbook II. Athens, United States: MicroMacro, 1996. 422 p.

MOHAMED, A.; EL-SOKKARY, I.; TUCKER, T. Growth and chlorophyll, mineral and total amino acid composition of tomato and wheat plants in relation to nitrogen and iron nutrition. II. Chlorophyll content and total amino acid composition. Journal of Plant Nutrition, New York, v. 10, p. $713-731,1987$.

PIEKIELEK, W. P.; FOX, R. H. Use of a chlorophyll meter to predict sidedress nitrogen requirements for maize. Agronomy Journal, Madison, v. 84, p. 59-65, 1992.

PIEKIELEK, W. P.; FOX, R. H.; TOTH, J. D.; MacNEAL, K. E. Use of a chlorophyll meter at the early dent stage of corn to evaluate nitrogen sufficiency. Agronomy Journal, Madison, v. 87, p. 403-408, 1995.

RHOADS, F. M.; OLSON, S. M.; HOCHMUTH, G. J.; HANLON, E. A. Yield and petiole-sap nitrate levels of tomato with $\mathrm{N}$ rates applied preplant or fertigated. Soil and Crop Science Society of Florida Annual Proceedings, Gainesville, v. 55, p. 9-12, 1996.

RODRIGUES, F. A.; FONTES, P. C. R.; MARTINEZ, H. E. P.; PEREIRA, P. R. G. Nível crítico do índice SPAD na folha da batateira, em solução nutritiva. Horticultura Brasileira, Brasília, v. 18, p. 764-765, 2000.

SAMPAIO, R. A.; FREITAS, J. A.; YUPANQUI, F. F. R.; FONTES, P. C. R.; MARTINEZ, H. E. P.; PEREIRA, P. R. G. Níveis críticos de $\mathrm{N}-\mathrm{NO}_{3}$ e N-orgânico em pecíolos de tomateiro de crescimento determinado. Revista Ceres, Viçosa, MG, v. 42, p. 444-452, 1995.

SANDOVAL-VILLA, M.; WOOD, C. W.; GUERTAL, E. A. Ammonium concentration in solution affects chlorophyll meter readings in tomato leaves. Journal of Plant Nutrition, New York, v. 22, p. 1717-1729, 1999.

SHAPIRO, C. A. Using a chlorophyll meter to manage nitrogen applications to corn with high nitrate irrigation water. Communications in Soil Science and Plant Analysis, New York, v. 30, p. 1037-1049, 1999.

SMEAL, D.; ZHANG, H. Chlorophyll meter evaluation for nitrogen management in corn. Communications in Soil Science and Plant Analysis, New York, v. 25, p. 1495-1503, 1994.

SMITH, F. W.; LONERAGAN, J. F. Interpretation of plant analysis: concepts and principles. In: REUTER, D. J.; ROBINSON, J. B. (Ed.). Plant Analysis: an interpretation manual. 2. ed. Collingwood: Commonwealth Scientific and Industrial Research Organization, 1997. p. 3-33.

TAKEBE, M.; YONEYAMA, T.; INADA, K.; MURAKAMI, T. Spectral reflectance ratio of rice canopy for estimating crop nitrogen status. Plant Soil, v. 122, p. 295-297, 1990. 